\title{
BIOFUELS' UNBALANCED EQUATIONS: MISLEADING STATISTICS, NETWORKED KNOWLEDGE AND MEASURED PARAMETERS. PART 3: MODELLED MARGINAL AND SPARE LAND VERSUS OBSERVED ECOSYSTEMS
}

KATE B. SHOWERS

\section{Abstract}

Competition for land between food and fuel crops dampened enthusiasm for biofuels cultivation as a mechanism for reducing European Union (EU) carbon emissions. Non-agricultural crops grown on marginal non-agricultural land, referred to as thirdgeneration biofuels, were proposed as a solution. Researchers and analysts used globalised statistics, databases and models to search for biofuels cropland. Two new categories of land emerged: the African Guinea Savannah Zone and global spare land. Guided by environmental history, a desktop ground-truthing exercise enabled a preliminary assessment of the largest regions of this newly 'discovered' land.

Keywords: European Union energy policy, Guinea Savannah Zone, unused land, climate change, GAEZ, intensified grazing systems

\section{Introduction}

Modelling has been widely used in constructing the responses of the European Union (EU) to Kyoto-mandated greenhouse gas emissions curtailment. Increasingly sophisticated computer capabilities, advances in information technology and globalised statistics enabled calculations supporting arguments for replacing fossil fuels with agrofuels (biofuels made from agricultural crops). Near-universal enthusiasm surrounded national and EU directives to process excess oil crops into biodiesel, and grain and sugar crops into bioethanol. However, at implementation, the modelled world collided with agronomic reality. The EU had neither enough 
crop surpluses nor-even with expansion—sufficient land under favourable growing conditions for biofuel feedstock cultivation. ${ }^{1}$ In response, a global market was created to stimulate biofuels feedstock production in poor countries. Agrofuels were supposed to provide a new revenue stream for achieving Millennium Development Goals. When land competition between food and fuel became apparent, so-called second-generation (non-food) biofuels were proposed. Agrofuels were renamed first-generation biofuels. Crop residues, forest by-products and lignaceous nonagricultural crops were to be converted into biofuels using still-theoretical production processes. However, long-term agronomic and forestry data from diverse locations and ecosystems demonstrated serious negative consequences. Third-generation biofuel crops were then defined: non-food crops grown on non-agricultural land at industrial scales. This shifted attention from crops to soils: non-agricultural land had to be defined and located.

A decade after the first biofuels directives, both global databases and models had increased in complexity. New model-based analyses of the potential for agricultural expansion introduced two concepts: Africa's Guinea Savannah Zone and 'global spare land'. The former has a specific geographical context and reaffirms colonial assumptions about the continent of Africa. In contrast, global spare land is not linked to any place and, therefore, implies the absence of conflict with human activity. Global spare land is a soothing antidote to assertions of biogeographical and sociocultural limits to biofuels production. Since both new land categories have entered the larger literature, as well as discussion down to the level of student papers, it is worth examining the origins of these concepts and the validity of their use.

Of particular interest to the biofuels community are two publications from authoritative institutions apparently documenting substantial amounts of suitable land. The World Bank's Awakening Africa's Sleeping Giant: Prospects for Commercial Agriculture in the Guinea Savannah Zone and Beyond presents maps of modelled marginal land identified as the African Guinea Savannah Zone. ${ }^{2}$ The Scientific Committee on Problems of the Environment (SCOPE)'s Bioenergy and Sustainability: Bridging the Gaps uses tables to assert the existence of global spare land of good quality. ${ }^{3}$ As a contribution to the discussion of constraints to biofuels production, an environmental history-based preliminary desktop ground-truthing exercise was carried out to confirm the accuracy of these modelled global projections.

\footnotetext{
1 Kate B. Showers, 'Land Use from Below: Biofuels, Urbanization and Sustainable Soil Management in Europe and Africa', in The Challenge of Sustaining Soils: Natural and Social Ramifications of Biomass Production in a Changing World, ed. Verena Winiwarter and Martin H. Gerzabek (Vienna: Austrian Academy of Sciences, 2012).

2 World Bank, Awakening Africa's Sleeping Giant: Prospects for Commercial Agriculture in the Guinea Savannah Zone and Beyond (Washington, DC: World Bank, 2009).

3 Glaucia Mendes Souza et al., eds, Bioenergy and Sustainability: Bridging the Gap (Paris: Scientific Committee on Problems of the Environment, 2015).
} 
The following analysis builds upon ideas developed in Parts 1 and 2 of this series of papers regarding global soil, terrain and land database and model construction, sources of bias, professional networking and circular citations. ${ }^{4}$ Assessing the reliability of the two publications involved posing basic questions from agronomic, environmental and environmental history perspectives. What definitions, methodologies and technologies had been used to identify the land cited? To what extent were the models and databases self-referencing? What would be the consequences of introducing the proposed intensified livestock management systems to release land for biofuels feedstock production at an industrial scale? Finally, since both reports were written without field verification, what is known about the actual properties of the landscapes identified, their past uses and current conditions?

\section{Defining unused land}

Digitisation enabled data manufacture and manipulation. Applying emerging technologies, researchers collaborated to produce soil, land and terrain databases, and models at a global scale. ${ }^{5}$ In response to critics' assertions of exacerbated worldwide land shortage, biofuels' advocates reinterpreted data used in earlier analyses of agricultural land databases, and applied models based on geographic information systems (GIS) to search for vacant land.

Proponents' calls for third-generation biofuels to be grown on marginal nonagricultural land marked a retreat to abstraction. There is no universal definition of marginal land. Sarah Lewis and Maggi Kelly's 2014 review of GIS-based biofuels analyses found general theoretical agreement that marginal land was land unsuited for agriculture. ${ }^{6}$

However, each set of authors had a different working definition to guide decisions made about and within model operation. The amount of land identified depended upon the criteria applied for land use, land rights and land ownership, as well as soil, terrain and climate characteristics. The earliest estimates came from simple

\footnotetext{
4 Kate B. Showers, 'Biofuels' unbalanced equations: Misleading statistics, networked knowledge and measured parameters. Part 1: Evolution of globalised soil, land and terrain databases', International Review of Environmental History 5, no. 1 (2019): 61-83, doi.org/10.22459/IREH.05.01.2019.05; Kate B. Showers, 'Biofuels' unbalanced equations: Misleading statistics, networked knowledge and measured parameters: Part 2. Networks, consensus and power', International Review of Environmental History 5, no. 2 (2019): 41-65, doi.org/10.22459/IREH.05.02.2019.02. 5 See Showers, 'Biofuels' unbalanced equations', parts 1 and 2.

6 Sarah M. Lewis and Maggi Kelly, 'Mapping the Potential for Biofuel Production on Marginal Lands: Differences in Definitions, Data and Models Across Scales', ISPRS International Journal of Geo-Information 3 (2014): 430-59, doi.org/10.3390/ijgi3020430.
} 
analyses of available databases - first at the national and regional levels, then at the global scale. Promoting the use of marginal land instead of the earlier category of 'potentially arable land' implied new land had been identified.'

\section{Marginal land}

Marginal land has been defined in terms of both biophysical and economic criteria. A United Nations Educational, Scientific and Cultural Organization (UNESCO) glossary defined marginal land as being of poor quality, largely unsuitable for cultivation due to nutrient deficiencies, dryness or susceptibility to erosion, and included notions of degraded land and wasteland. ${ }^{8}$ The UN Environment Programme identified degraded land as that which had a long-term loss of ecosystem function and services caused by disturbances from which the system could not recover unaided. ${ }^{9}$ L. R. Oldeman et al., creators of the Global Assessment of Soil Degradation (GLASOD) database, ${ }^{10}$ defined wasteland as land without appreciable cover or agricultural potential, consisting of six types-active dunes, salt flats, rock outcrops, deserts, ice caps and arid mountain regions. ${ }^{11}$ Soils in these places are fragile and particularly prone to further degradation if cultivated. Using them would require substantial investment in comprehensive research concerning their properties and management, as well as in soil amendments.

In contrast, economists have created a relative, non-biophysical definition of marginal land based on use value. This definition fits well with derived and digitised land resource databases. George Peterson and John Kenneth Galbraith theorised marginal land as that which is peripheral to commercial agricultural production, or land on which the cost of production equals the revenues from optimal production. ${ }^{12}$ The Consortium of International Agricultural Research Centers expanded the definition of marginal land to include the people dependent upon it. Marginal people are those facing socioeconomic constraints. Concentrations of marginal people farming marginal land constituted a marginal area. Agricultural development projects could be usefully directed at marginal areas (which could contain both marginal and

\footnotetext{
7 The concept of potentially arable land was introduced in A. J. Bot, F. O. Nachtergaele and A. Young, Land Resource Potential and Constraints at Regional and Country Levels (World Soil Resources Reports, 90) (Rome: FAO Land and Water Development Division, 2000), www.fao.org/3/a-x7126e.pdf, accessed 21 January 2020. See Showers, 'Biofuels' unbalanced equations', part 1 for detailed discussion.

8 United Nations Educational, Scientific and Cultural Organization, 'Glossary', www.unesco.org/education/tldf/ TLSF/intro/glossary_links/glossary.htm, accessed 5 August 2011.

9 United Nations Environment Programme, Global Environmental Outlook (GEO-4) (Nairobi: UNEP, 2007).

10 See Showers, 'Biofuels' unbalanced equations', part 1.

11 L. R. Oldeman, R. T. A. Hakkeling and W. G. Sombroek, World Map of the Status of Human-induced Soil Degradation: Explanatory Note (Wageningen: International Soil Reference and Information Centre; Nairobi: UNEP, 1990).

12 G. M. Peterson and J. K. Galbraith, 'The Concept of Marginal Land', Journal of Farm Economics 14 (1932): 295-310, doi.org/10.2307/1230112.
} 
favoured land) if measurable economic change could be imagined. Marginal lands were further subdivided into land with high and low expectations of a productivity response to changes resulting from agricultural research. ${ }^{13}$

Promoters of third-generation biofuels have based their advocacy on estimates of economically defined marginal land. However, critics have noted mythic beliefs attached to the extent and potential of marginal land.$^{14}$ In 2007, Richard Doornbosch and Ronald Steenblick warned that reliable estimates do not exist, since doublecounting was widespread and the UN Food and Agriculture Organization (FAO) figures consistently underestimated the amount of land already in use. ${ }^{15}$

\section{Global spare land}

Global spare land was identified and named by version 3.0 of the Global AgroEcological Zone (GAEZ). ${ }^{16}$ The AEZ-GAEZ model family resulted from a collaboration between the International Institute for Applied Systems Analysis (IIASA) and the FAO. The widely used 2002 GAEZ version 2.0 had identified 'potentially arable land' that included inhabited areas and the tropical rainforests of the Amazon and Congo basins. In contrast, the 2012 version 3.0 excluded urban areas, forests and protected land. Instead, land supporting wild ungulates and extensive grazing of domestic livestock was coded as underutilised. As a result, grassland (savannah, plains, prairie) was classed as prime or good 'spare land' that could be brought into cultivation. ${ }^{17}$

\section{Finding unused land}

Models replaced explorers in the early twenty-first-century search for unused agricultural land. In 2009, a World Bank team of economists announced the discovery of Africa's Guinea Savannah Zone. It was described in their report Awakening Africa's Sleeping Giant, which was a study of the potential for large-scale commercial agriculture on the African continent. The new zone consisted of two broad bands stretching across the continent, together with some scattered fragments and part of an island. The African Guinea Savannah was described as having

13 Consortium of International Agricultural Research Centers, 'CGIAR Research Priorities for Marginal Lands'. Document No SDR/TAC:IAR/99/12 (Washington, DC: Technical Advisory Committee of the CGIAR, 2001).

14 ibid.; Gaia Foundation et al., Agrofuels and the Myth of the Marginal Lands, 2008, www.cbd.int/doc/biofuel/ Econexus Briefing AgrofuelsMarginalMyth.pdf, accessed 1 June 2017.

15 R. Doornbosch and R. Steenblick, 'Biofuels: Is the Cure Worse than the Disease?', Revista Virtual Redesma (July 2008), calepa.ca.gov/wp-content/uploads/sites/6/2016/10/CEPC-2010yr-AsltonBird-AppAEx3.pdf, accessed 21 April 2020.

16 International Institute of Applied Systems Analysis / Food and Agriculture Organization, Global Agro-ecological Zones, Documentation GAEZ ver 3.0 (Laxenburg: IIASA; Rome, FAO, 2012).

17 IIASA/FAO, Global Agro-ecological Zones. 
important characteristics for crop production. It was 'one of the major underutilized resources in Africa', 'one of the largest underused agricultural reserves in the world' and a 'very large agroecological zone that is recognized as significantly underutilized'. Its extent was said to be ' 600 or 700 million ha, 400 million ha of which can be used for agriculture', less than 10 per cent of which was used for crops. ${ }^{18}$

Six years later, a report by the Paris-based SCOPE declared the end of land constraints to biofuels production due to abundant newly discovered global spare land. Bioenergy and Sustainability was the result of a rapid assessment process carried out at a workshop. Fifty 'experts' from 13 countries met in Paris to hold 'crosscutting discussions' on four themes (Energy Security, Food Security, Environmental and Climate Security, and Sustainable Development and Innovation) based on background chapters commissioned before the workshop. The editors of the resulting report thus were able to claim to have drawn on contributions by 137 individuals from 82 institutions and 24 countries. ${ }^{19}$ These numbers implied international authority and consensus for the assertion that 1.4 billion hectares of global spare land classed as good or prime was available for biofuels cultivation. Sixty per cent of this land existed in just 13 countries: Brazil, the United States, the Russian Federation, Argentina, Australia, Sudan, China, the Democratic Republic of Congo (DRC), Kazakhstan, Angola, Canada, Mozambique and Madagascar (in descending order).

\section{Creating landscapes}

The African Guinea Savannah Zone, a model output expressed in map form, is credited to the International Food Policy Research Institute (IFPRI). The mapped zone originated in a data set published by Kate Sebastian in 2009 (v.2 released in 2013). ${ }^{20}$ Operating at a regional scale, the zone was defined as 'geographical areas exhibiting similar climatic conditions that determine their ability to support rainfed agriculture' ${ }^{21}$

Three categories had been used to identify the African agroecological zone: major climate zone (tropics or subtropics), moisture zones (water availability) and highland/lowland (warm or cool, based on elevation). ${ }^{22}$ Soils in the identified area were described using US Department of Agriculture (USDA) Soil Taxonomy at

18 World Bank, Awakening Africa's Sleeping Giant.

19 Souza et al., Bioenergy and Sustainability.

20 Kate Sebastian, 'Agro-ecological Zones of Africa Dataset', IFPRI, 2009, www.ifpri.org and dataverse.harvard. edu/dataset.xhtml?persistentId=hdl:1902.1/22616, accessed 16 March 2016.

21 Sebastian, 'Agro-ecological Zones of Africa Dataset'.

22 ibid. 
the order level of classification, and were summarised as being of poor quality. ${ }^{23}$ The modelled African Guinea Savannah Zone was revised after comments from World Bank 'experts'. ${ }^{24}$

The actual map was produced by the World Bank's Jeff Lecksell, based upon information provided by Stanley Wood and Zhe Guo at IFPRI. ${ }^{25}$ The map was 'developed using [Jami L.] Dixon's farming systems data, the length of growth period from IIASA (or some remote sensing product) [sic], and [the] revised version of Agro-ecological Zones developed by IFPRI' ${ }^{26}$

FAO's John A. Dixon et al., ${ }^{27}$ commissioned by the World Bank, had classified the world's farming systems according to: 1 . the availability of the natural resource base; 2. the identified dominant pattern of farming and household livelihood; and 3. the intensity of production. This framework was then 'applied to the 6 main regions of the developing world', resulting in ' 72 farming systems with more than approximately 40 million inhabitants'. ${ }^{28}$ To reduce detail, the systems were further consolidated into eight major categories, which produced 'considerable heterogeneity within each delineated zone'. ${ }^{29}$ Quantitative analysis of farming systems productivity relied upon the statistics provided in Nikos Alexandratos and Jelle Bruinsma's World Agriculture: Toward 2015/30: Interim Report. ${ }^{30}$ This report, in turn, presented the results of FAO/ IIASA's GAEZ v.1, which had been first published as the TERRASTAT database. ${ }^{31}$ Because it included both the Amazon and Congo River rainforests, GAEZ version 1.0 analysis had shown 90 per cent of the world's remaining 'potential arable land' for agricultural expansion to be in Latin America and sub-Saharan Africa.

The World Bank economic team used the IFPRI reinterpretation of FAO data for the continent of Africa. This continental scale of analysis was then applied in a case study of comparative analyses with 'similar regions' in the countries of Brazil and Thailand. The result was an optimistic report asserting the existence of an extensive, previously unrecognised and currently unused 'ecological zone' suitable for largescale agriculture on the African continent.

The GAEZ model family was also an integral part of the SCOPE report. Central to the analysis of Bioenergy and Sustainability was Alexandratos and Bruinsma's World Agriculture: Towards 2030/2050: The 2012 Revision. This report was based on

23 World Bank, Awakening Africa's Sleeping Giant, 25.

24 Zhe Guo, via Michael Go, IFPRI. Email to author, 6 April 2016.

25 Guo, email to author, 6 April 2016.

26 ibid.

27 J. A. Dixon, A. Gulliver and D. P. Gibben, Farming Systems and Poverty: Improving Farmers' Livelihoods in a Changing World (Rome: FAO and Washington, DC: World Bank, 2001).

28 ibid., 2.

29 ibid.

30 FAO, World Agriculture: Towards 2015/30: Interim Report (Rome: FAO, 2000).

31 Discussed in detail in Showers, 'Biofuels' unbalanced equations', part 1. 
data from the 2012 update of GAEZ version 3.0. It had produced higher estimates of unused land than had the widely used version 2.0 or the 2011 update of 3.0. Alexandratos and Bruinsma discussed the difficulty in determining the reasons for the inconsistencies. Different databases and other variables had been used. ${ }^{32}$ In the SCOPE report, calculations were based on an estimated 7.2 billion hectares identified as having rain-fed production potential. After subtracting estimates of 1.6 billion hectares already under crops, 2.8 billion under forest and 1.5 billion of poor-quality land, an estimated 1.4 billion hectares of prime land remained - most of which was grassland. Because it had been coded as underutilised, this became the 'global spare land' that could be brought into cultivation.

\section{Denying diversity}

Fundamental to the creation of global statistics and databases-as well as models operating with them-is the idea of general descriptions of uniform entities. Averaging and data-smoothing techniques create homogeneous and harmonised globalised data sets and databases. ${ }^{33}$ Analysis at a global scale, therefore, has within its structure the conscious elimination of information and the deliberate suppression of variation. Researchers using these tools may apply analytical methods that further minimise differences or characteristics that distinguish one ecosystem or component from another.

The World Bank researchers avoided confronting diversity in two ways: scale and case study. Basing analysis on a continental map resulted in the loss of geography and the appearance of homogeneity. The mapped African Guinea Savannah Zone fails to indicate that the African continent constitutes 22 per cent of the earth's surface, that many countries are larger than those of Europe, and that the continent is diverse at all scales-from soil microbiology, flora and megafauna to geomorphic features and climate regimes. The assumed uniformity of the modelled African Guinea Savannah Zone obscures the range of soils included in the modelled zone: from the French system's ferrasols, ferralitic soils and fersialitic (ferruginous) soils across much of the indicated region of West Africa to FAO/SOTER's Arenosols, Lixisols, Calcisols and Luvisols in Mozambique. Local soil heterogeneity and complexity are importantif not essential-for landscape function and plant growth. The predominant, large and apparently flat dryland plateaus on which most African grasslands exist are actually complex mosaics of slightly inclined water-shedding and water-collecting (and storing) surfaces. This creates a variety of soil hydrological conditions within a relatively small area. Each supports not only diverse microbial communities but also physically small biota that increase or decrease water infiltration while supplying

32 Nikos Alexandratos and Jelle Bruinsma, eds, World Agriculture: Towards 2030/2050: The 2012 Revision (Rome: FAO, 2012)

33 Fully discussed in Showers, 'Biofuels' unbalanced equations', part 1. 
nutrients. Much of the indicated region has at least a six-month dry spell, with erratic rainfall during the wet season. In some places, this consists of two irregular rainy seasons of different lengths. Evapotranspiration rates can exceed precipitation during the growing season. These conditions present significant challenges for plant growth.

The Bioenergy and Sustainability analysis of global spare land is based upon modelled estimates. The editors responsibly call for further investigation for verification and to refine project development. Nevertheless, the report claims, without reservation, that not only does global spare land exist, but it does so in sufficient quantity to provide enough biofuels to mitigate greenhouse gas emissions without causing environmental harm or food insecurity.

\section{Ground-truthing model results}

Anyone can, and model makers and model users should, assess both the accuracy and the practicality of model results by initial comparisons with independent, measurement-based biogeographical descriptions, land-use evaluations and environmental histories. Particular attention should be paid to the quality of databases used, the consequences of model assumptions, and factors excluded from databases and models, as well as by the model operators.

\section{World Bank/IFPRI's African Guinea Savannah Zone}

Africa's Sleeping Giant purported to demonstrate the potential for economic development based on large-scale farming within the modelled zone, 'transforming the natural ecosystems found in the Guinea Savannah Zone into vibrant commercial farming systems [and] restoring agricultural competitiveness' ${ }^{34}$

Analysis was performed at the national level, obviating consideration of complications and constraints faced by individual farmers, regardless of their scale and type of operation. Only two of the 27 countries listed (Gambia and Guinea) lie entirely within the identified area. Therefore, the national statistics used in the analysis reflected the productivity of sometimes larger areas outside the modelled zone that have entirely different_-and perhaps more favourable_-soil and climate characteristics.

Consistent with the model's denial of diversity, the economists chose case-study analysis as their methodology. They selected three countries-Nigeria (West Africa), Zambia (Central Africa) and Mozambique (East and Southern Africa)—without mentioning their selection criteria. There is no discussion of how these three could 
represent the other mapped countries, or why the two falling entirely within the modelled zone had not been considered. It is unclear how Nigeria-whose economy has been so distorted by oil revenues that it gave rise to the term 'Oil Curse'and Zambia, dominated by its mineral and mining sector-could typify the other countries whose economies depend more on livestock and annual and perennial crop production. Nigeria and Mozambique are similar in having had post-independence wars. Nigeria's was a destructive, but limited, civil war (stimulated by oil), followed by military rule. Mozambique was, for 30 years, a target of Apartheid South Africa's military. In the early twenty-first century, there were, still, undetonated and unmapped landmines scattered throughout the countryside, particularly near agricultural areas. ${ }^{35}$ Most of the other countries have not been defined by war. Unlike all of West Africa and some countries in Central and East Africa, Zambia had a large European settler population that at independence controlled extensive areas of the best agricultural land, as well as dominating the mining sector. What all 27 do have in common is a lack of soil amendments required for large-scale crop production, minimal infrastructure and a general paucity of transport.

An underlying assumption was that the modelled African Guinea Savannah Zone constituted an unused 'natural ecosystem', ready for transformation. ${ }^{36}$ However, extensive land-use patterns explain the report's characterisation of a region with low population densities. Much of the mapped area is classified as having semi-arid to arid climate regimes. With sparse and unpredictable rainfall, there is a long history of agro-pastoralism and pastoralism. Drought-tolerant perennial crops, such as western Sudan's Acacia senegal trees, which produce high-quality (and high-priced) gum arabic, have long provided economic value to sandy soils unable to support grain or vegetable crops. The authors indirectly recognised the fallacy of equating population density with land availability. They noted that because 'virtually no area is entirely unused or unclaimed', land tenure would 'certainly pose a significant problem because commercial agricultural development could not be achieved without converting forest and pastureland' ${ }^{37}$ The World Bank's World Development Report 2008 notes that when population density is adjusted for land quality, much of sub-Saharan Africa resembles Asia in terms of land shortage. ${ }^{38}$ By this calculation, Kenya, whose western fringe is in the modelled African Guinea Savannah Zone, has a population density higher than that of Bangladesh. ${ }^{39}$ Whether or not the case study analysis accurately reflects the three selected countries, it is highly unlikely that the analysis warrants generalisation to the other 24 in the mapped zone.

35 ListVerse, '10 Countries with the Most Landmines', listverse.com/2008/08/11/10-countries-with-the-mostlandmines, accessed 28 August 2015; Landmine and Cluster Munition Monitor, 'Frequently asked questions', www.the-monitor.org/en-gb/the-issues/faqs/most-common.aspx, accessed 1 June 2017.

36 World Bank, Awakening Africa's Sleeping Giant, 20.

37 ibid., 10 .

38 World Bank, World Development Report 2008: Agriculture and Development (Washington, DC: World Bank, 2007).

39 ibid. 
The inaccuracy of intercontinental agricultural extrapolation was subsequently confirmed in Mozambique. In 2009, the same year that Africa's Sleeping Giant had been released, a joint project was announced between the government of Mozambique, the Japan International Cooperation Agency and the Brazilian Cooperation Agency to develop large-scale commercial agriculture in the Nacala Corridor of Mozambique. ${ }^{40}$ Called ProSavana, the project was to include 19 districts in three northern provinces, covering 14 million hectares considered suitable for cultivating export crops of soybeans, cotton and maize. The project was to be modelled on the Japanese-supported 1970-90 conversion of Brazil's Cerrado into one of the world's most profitable soybean-growing areas. However, when the Mozambique region's many small farmers saw the destructive effects of Agromoz, an early Brazilian-Portuguese joint venture in Nacala, rural resistance spread. Local observations were confirmed by a National Farmer's Union (UNAC) trip to Brazil's Cerrado in 2012. The delegation was shocked by the sterility of the agro-industrial landscape-devoid of wildlife, plant diversity and people. Demonstrations against ProSavana began, and protests spread throughout Mozambique. Project funds were withdrawn, and the Japanese official who was responsible, Hiroshi Yokoyama, is quoted as having said:

We made a gross error of judgement. At the start, we thought it would be possible to reproduce the Mato Grosso experiment. Then we realized [Nacala and Mato Grosso] were very different, and that it wouldn't be appropriate to apply a Brazilian development model here. ${ }^{41}$

\section{IIASA/FAO and SCOPE's global spare land}

Because the African Guinea Savannah Zone and global spare land are linked by the GAEZ model, there is an overlap of four nations identified with 'unused land': Angola, the DRC, Mozambique and Sudan. They share recent experiences of war and limited field-based soil information. Angola endured a civil war, as well as being a target of Apartheid South African aggression, and semi-arid to arid North and South Sudan's border area (a division unacknowledged in either model) was a battleground in the early twenty-first century. The south-eastern part of the DRC (included in the African Guinea Savannah Zone) is a mineral-rich region with multinational mining interests and was an active war zone in the late twentieth and early twenty-first centuries. Despite the soils of the DRC having been listed on the FAO/UNESCO paper map as being 'virtually unknown', a modelled DRC soil map exists. Soil scientists using the SOTER Digital Database had created a Central African soil map using virtual soil profiles and extrapolation from known data. ${ }^{42}$

40 For detailed discussion, see Stefano Liberti, 'Mozambique Won't be Mato Grosso', Le Monde Diplomatique, June 2018, 8-9.

41 ibid., 9.

42 A UNEP-FAO-International Soil Resource Information Centre collaboration. For a description of SOTER, see Showers, 'Biofuels' unbalanced equations', part 1. 
However, the four countries GAEZ v.3.0 identified as containing the most spare land are not on the African continent. They are located in South and North America and Eurasia- the latter two described by earlier versions of GAEZ as having little available unused land. The following descriptions of the spare land identified in the top four countries-Brazil, the United States, the Russian Federation and Argentina-should raise fundamental questions not only about the concept of spare land, but also about the validity of exploring for land using computer modelling and simulation.

\section{Brazil's Cerrado biome}

Cerrado, the name given to the natural vegetation covering 200 million hectares of the Brazilian interior, ranges from treeless grasslands and grasslands with sparse trees and shrubs to closed xeromorphic forests (called cerradão). ${ }^{43}$ The extremely flat landscape has very old and weathered soils. They are classified in the USDA Soil Taxonomy primarily as oxisols (ferralitic soils), with some ultisols. These dystrophic soils are acidic (very low $\mathrm{pH}$ ) and have little ability to retain the few base minerals that exist. It is aluminium, rather than the bases, that dominates the ion exchange system and determines which organisms can survive in the biome. The soils also have very low levels of phosphorus, little of which is in a form available to plants. ${ }^{44}$

Despite harsh growing conditions, the cerrado biome has been designated a biodiversity hotspot, containing an estimated 160,000 species of plants, fungi and animals, with at least 90,000 species of insects, 40,000 species of fungi, 10,000 species of angisperms, 150 species of mammals, 550 species of birds and a highly varied soil microbial community. ${ }^{45}$ The physiological and ecological characteristics and significance of the soil microbial communities are only beginning to be understood. Nitrogen-fixing bacteria have long been recognised in cerrado soils. Janaina Araujo et al. posit that microbial biomass also conserves a considerable portion of available soil phosphorus. ${ }^{46}$ In addition, acidobacteria phyla-prolific producers of secondary metabolites, such as antimicrobial compounds-could be important in the suppression of other bacterial populations. The unique and resilient cerrado biome has been largely unstudied, and remains unprotected. In the early twenty-first century, there was extensive land conversion for soybeans, biofuels and livestock production; the remaining undisturbed cerrado is under serious threat.

43 Peter A. Furley and James A. Ratter, 'Soil Resources and Plant Communities of the Central Brazilian Cerrado and their Development', Journal of Biogeography 15 (1998): 97-108, doi.org/10.2307/2845050.

44 Furley and Ratter, 'Soil Resources'.

45 Janaina F. Araujo et al., 'Characterization of Soil Bacteria Assemblies in Brazilian Savanna-like Vegetation Reveals Acidobacteria Dominance’, Microbial Ecology 64 (2012): 760-70, doi.org/10.1007/s00248-012-0057-3; J. A. Ratter, J. F. Ribeiro and S. Bridgewater, 'The Brazilian Cerrado Vegetation and Threats to its Diversity', Annals of Botany 80 (1997): 223-30, doi.org/10.1006/anbo.1997.0469.

46 Araujo et al., 'Characterization of Soil Bacteria Assemblies'. 
The biome's contribution to global processes has not been elaborated, but both vegetative and soil biota sequester large amounts of carbon. Since surface albedo is important in models of local, regional and global climate patterns, what would be the significance of transforming 200 million hectares of cerrado vegetation to the darker surfaces of oxisols and ultisols with agricultural crops? What would happen seasonally and annually to local, regional and global hydrologies if the cerrado transpiration rhythms and amounts were disrupted and replaced by intensive, irrigated monocrop systems? Finally, what would be the consequences of rhizosphere disturbance, if not destruction, and how would it be manifested?

\section{The United States and Canada's Prairie Pothole Region}

Much of the central North American prairies (called the Corn Belt in the United States) was ploughed for grain production in the twentieth century. Converting the remaining prairie land to cultivated fields for biofuels was theoretically calculated before, and studied after, implementation in 10 states of the Corn Belt. Using experiment station research data in computer models, Ilya Gelfand et al. calculated the possibility of producing 21 gigalitres of ethanol/year from cellulosic feedstocks planted on approximately 11 million hectares of fertilised marginal land without any initial carbon debt or indirect land-use costs. ${ }^{47}$ Defying model predictions, the prairies underwent radical land cover/land use change following the implementation of government policies promoting biofuels cultivation. Christopher Wright and Michael Wimberly made an actual regional accounting of grassland conversion consequences between 2006 and 2011 in the western Corn Belt states containing the most remaining grass-dominated land cover. Destruction rivalled that of the 1920s-30s era of agricultural mechanisation. They found conversion rates of 1.0-5.4 per cent per year. These rates are comparable to those of the 1980s-90s deforestation associated with agricultural expansion in Brazil, Malaysia and Indonesia that caused international alarm..$^{48}$ Prairie loss is less shocking because industrial societies value grasses less than trees. Consequently, the temperate grassland biome is the most altered globally and least protected. Conversion of the Corn Belt's indigenous pre-settlement tall grass prairie land has larger regional, and global, significance because it includes the Prairie Pothole Region and Nebraska Sand Hills.

The Prairie Pothole Region (extending north into Canada) is the most productive waterfowl-breeding habitat in North America, as well as an important breeding ground for Neotropical migratory shorebirds. Biofuels cultivation encroached upon the grassland adjoining wetlands. These areas are critical to the success of duck breeding because they reduce predation. Grassland conversion also occurred in land previously set aside in conservation reserve programs. The resulting loss of grass

47 I. R. Gelfand et al., 'Sustainable Bioenergy Production from Marginal Lands in the US Midwest', Nature 493 (24 January 2013): 514-19, doi.org/10.1038/nature11811.

48 Christopher K. Wright and Michael C. Wimberly, 'Recent Land Use Change in the Western Corn Belt Threatens Grasslands and Wetlands', PNAS 110 (5 March 2013): 4134-9, doi.org/10.1073/pnas.1215404110. 
cover brought more erodible soils into cultivation. As a result, there was decreased soil capacity, declining carbon sequestration, increased sediment transportation into wetlands, changed surface water hydrology, increased peak flows and modified stream morphology. ${ }^{49}$

The 49,210,000-hectare Nebraska Sand Hills is the largest sand dune area in the western hemisphere. However, it enables irrigated agriculture because the Sand Hills contribute 30 per cent of the recharge water for the High Plains Aquifer underlying the western Corn Belt. Research has demonstrated that the natural grassland cover supporting extensive grazing is protective and resilient. If physically removed, wind erosion occurs at rates up to 1 metre per year. When left in place, even if drought desiccates above-ground plant parts, the below-ground ecosystem minimises sand movement. There is a residual buffering effect even after it, too, succumbs. Replacing native grasses with trees resulted in soil moisture depletion to greater depths. Research results further supported suggestions of strong feedbacks on local and regional climate in temperate semi-arid regions. ${ }^{50}$

Model-generated proposals for cultivating the Corn Belt's remaining prairie ecosystems have not taken into account the region's significance for national and international avian populations, regional aquifer recharge, climatic regimes or the complex interactions and significance of below-ground root systems, not only for local soil stability but also for carbon sequestration.

\section{The Russian Federation's abandoned farmland}

The GAEZ model's identification of the Russian Federation's abandoned farmland as the third-largest source of global spare land resembles the early optimism for the EU's self-sufficiency in agrofuels. Projections had been based upon expectations of increased farmland from an expanded EU. ${ }^{51}$ Eastern Europe's chronically low yields had been attributed to socialism and central planning/management, but closer agronomic analysis demonstrated soil and climate constraints.

According to Grigory Ioffe and Tatyana Nefedova, ${ }^{52}$ Russian farmers face the worst climate factors anywhere in the world. Ninety million of the Russian Federation's 119 million hectares of arable land are limited by severe winter temperatures, short growing seasons, depth of soil freezing and erratic patterns of severe cold and thaws. Of the total rural land area, 10 per cent is favourable for cultivation, 40 per cent is

\footnotetext{
49 ibid.

50 David A. Wedin, 'Trees, Shrubs, Grasses and the Nebraska Sand Hills: Experimental Ecohydrology and Below Ground Ecology', School of Natural Resources, University of Nebraska, USDA Research, Education and Economics Information System, 2006, reeis.usda.gov/web/crisprojectpages/0206041-trees-shrubs-grasses-and-the-nebraskasandhills-experimental-ecohydrology-and-belowground-ecology.html, accessed 14 December 2018.

51 Showers, 'Land Use from Below'.

52 Grigory Ioffe and Tatyana Nefedeva, 'Marginal Farmland in European Russia', Eurasian Geography and Economics 45 (2004): 31-45, doi.org/10.2747/1538-7216.45.1.45.
} 
submarginal and half is ill-suited. In terms of degree days above $10^{\circ} \mathrm{C}$ (mean annual daily temperature) and precipitation-to-evaporation ratios, 59 per cent of Russian agricultural production occurs on submarginal land. Thirty-eight per cent of European Russia is marginally cold, and 27 per cent submarginally cold. Sixteen per cent of the arable land has a 70-90 per cent chance of drought, and a third is in semi-arid areas with drought every third year.

From 1980 to 2000, approximately 20 million hectares of arable land were abandoned. Except for the region around Moscow, where land is used for second homes, land abandonment increased at distances greater than two hours' travel from an urban area. This was particularly pronounced in the lower soil fertility nonchernozem soil zone. With significant investment-from fertiliser to infrastructure construction - and a tolerance for risk of climate extremes, abandoned farmland could be cultivated for biofuels. But this would be without reliability of either production or profits.

\section{Argentina's Caldenal}

The transition zone between central Argentina's Humid Pampas and Patagonia regions is a phytogeographic zone called the Caldenal. Originally the area was an extensive grassland with isolated bushes and trees. A mutual water-dependent relationship existed between the vegetation and soil in response to the significant variability in rainfall $(109-761 \mathrm{~mm} /$ year) and elevated evapotranspiration rates (as high as $1220 \mathrm{~mm}$ ). Roots proliferated in the top $5 \mathrm{~cm}$ of soil to enable more efficient use of what rain did fall. ${ }^{53}$ The rhizosphere included a dependent microbial community (e.g. mycorrhiza, Azospirillum bacteria), which provided nutrients and increased water availability. ${ }^{54}$ The calcareous and, in places, saline soils have pedogenic carbonates and calcic horizons. ${ }^{55}$ Because of their low structural stability and texture, the soils are extremely susceptible to wind erosion..$^{56}$

In the early twentieth century, livestock breeders began to establish ranches in the region. By the end of the century, the Caldenal was in an advanced state of degradation and desertification. Intensely grazed, lightly grazed or ungrazed patches had bare soil as a constant feature. ${ }^{57}$ The microbial community had also been

53 María Bomita Villamil et al., 'Soil Degradation Related to Overgrazing in the Semi-arid Southern Caldera Area of Argentina', Soil Science 166 (2001).

54 Y. Bashan and P. Vazquez, 'Effect of Calcium Carbonate, Sand and Organic Matter Levels on Mortality of 5 Species of Azospirillum in Natural and Artificial Bulk Soils', Biology and Fertility of Soils 30 (2000), doi. org/10.1007/s003740050023; Villamil et al., 'Soil Degradation'.

55 J. D. Patil and N. D. Patil, 'Effect of Calcium Carbonate and Organic Matter on the Growth and Concentration of Iron and Manganese in Sorghum (Sorghum Bicolor)', Plant and Soil 60, no. 2 (1981): 295-300; J. D. Paoloni et al., 'Water resources in the semi-arid Pampa-Patagonia transitional region of Argentina', Journal of Arid Environments 53, no. 2 (2003): 257-70.

56 Paoloni et al., 'Water resources'.

57 Villamil et al., 'Soil Degradation'. 
weakened by having its food source removed. Animal traffic affected soil structure, bulk density, total porosity and pore size distribution, as well as aggregate stability. These physical alterations, in turn, affected water infiltration rates, water retention capacity, structural stability and microbial communities. Researchers believe that many of the soil changes will not be reversible in the short term. As yet undetermined threshold levels will mark irreversibility. ${ }^{58}$

Crop cultivation would be restricted by the high levels of calcium carbonate, which decrease the availability of iron, manganese, micronutrients and phosphorus. Groundwater, containing arsenic, sulphates and magnesium, as well as sodium and chloride, is below acceptable levels for human consumption. However, these levels can support livestock once they become accustomed to them. ${ }^{59}$ Much of the region is seriously degraded and the remaining Caldenal vegetation is under threat. Proposed intensified land-use systems would contribute to further destruction.

\section{Intensifying grazing systems to release land}

Plans for industrial-scale biofuels cultivation in grasslands assume that intensified grazing and livestock management systems will displace existing extensive grazing systems. The theorised result is a release of land for agriculture. The FAO's Alexandratos and Bruinsma conceded that a shift from extensive grazing to stall-fed management would raise the average grain-to-meat ratios. ${ }^{60}$ The imagined 'freed' land would actually be required to produce grain for confined cattle, and thus not be available for biofuels cultivation.

\section{North America}

Feedlots began in the United States in the 1850s to solve a waste-management problem associated with cotton seed oil extraction. Cattle were fed the large amounts of meal and hull by-products in need of disposal. Within 50 years, a separate feedlot industry had emerged. By 2012 the United States had the largest fed-cattle industry in the world. ${ }^{61}$ Expansion caused increasing disconnection from rangeland, making producers responsible for elements that had previously come from ecosystem function. In the most extreme forms, cattle are indoors from birth to slaughter. They require not only food and water supplies, but also climate management. Cattle's water requirements can be calculated fairly easily. The same is not true for

58 ibid.; Bashan and Vazquez, 'Effect of Calcium Carbonate'.

59 Paoloni et al., 'Water resources'.

60 Alexandratos and Bruinsma, World Agriculture: Towards 2030/2050.

61 Charles E. Ball, 'Cattle Feeding', Handbook of Texas Online, Texas State Historical Association, www.tsha online.org/handbook/online/articles/aucrw, accessed 2 November 2015; USDA ERS, 'Cattle and Beef. Cattle: Background', Economic Research Service, US Department of Agriculture, 2011, www.ers.usda.gov/topics/animalproducts/cattle-beef/background.aspx, accessed 2 November 2015. 
estimating the amount of land required to sustain the livestock. The diversity of feed and fodder is the first complication. The amount consumed varies with animal age, rate of weight gain, and desired meat classification at the end of life. Regardless of size or configuration, all feedlots must have some mechanisms for feeding and waste management.

The pollution potential of feedlots is great. In 1991, Gordon Conway and Jules Pretty calculated that in the United Kingdom the pollution load from livestock was equal to that of 150 million people (about 2.5 times the human population in 1991), and in the United States equal to 2 billion people ( 40 per cent of the estimated world population). ${ }^{62}$ Large-feedlot waste was equal to that of a small city. It was estimated that the nitrogen produced by two thirds of the feedlots in the US Midwest, if preserved and used, could equal $100 \mathrm{~kg}$ of nitrogen per hectare for 8.4 per cent of the wheat and maize grown in the nation. ${ }^{63}$ How does this North American prairie experience relate to intensified grazing systems proposed for South American biofuels production?

\section{South America}

In Brazil, subsidies have favoured establishing large, highly mechanised, capitalintensive forms of agriculture pioneered in the United States. Cattle ranching expanded rapidly on the cerradão savannah in the late twentieth century. By 2003, Brazil had become the largest beef exporter in the world, with the largest commercial cattle herd. However, the feedlots that began to emerge in the 1990s did not follow US environmental guidelines. The first national survey of Brazilian feedlot waste management practices found that on 73 (of 120 contacted) feedlots in seven states, 74 per cent of the respondents could not estimate the amount of manure produced. Twenty-six per cent estimated 2-4 kg of manure per animal per day on a dry matter basis. The most common manure-handling practice was removal from pens only at the end of the 60-135-day feeding period, followed by storage in mounds before spreading on crop and pasture lands. The operators had very little information about the properties of manure and how best to handle it. ${ }^{64}$ On this weak experiential and knowledge base comes great pressure to increase the number and size of feedlots.

Land use has been identified as Brazil's primary source of elevated greenhouse gas emissions. The first source was cutting down the Atlantic coastal forests and the Amazon rainforests for expanded biofuels production (sugar cane). This was followed by transforming the cerrado into agricultural fields and cattle ranching.

62 Gordon Conway and Jules Pretty, Unwelcome Harvest: Agriculture and Pollution (London: Earthscan, 1991).

63 Babman Eghball and F. Power, 'Beef Cattle Feedlot Manure Management', Journal of Soil and Water Conservation 49, no. 2 (1994): 113-22.

64 C. Costa et al., 'Brazilian beef cattle feedlot manure management: A country survey', Journal of Animal Science 91, no. 4 (2013): 1811-18. 
Yet intensification of farming and livestock production has been designated by the United Nations Framework Convention on Climate Change a Nationally Appropriate Mitigation Action. Cattle Ranching Intensification Programs on abandoned and marginal land have been proposed as a land-sparing activity. Proponents claim that increased technology adoption would produce increased crop yields and livestock production per unit of land. This, in turn, would result in decreased demand for pasture and agricultural land, thus reducing deforestation. ${ }^{65}$

One proposal for the application of advanced technology is Intensive Cattle on Pivot Irrigation Systems, in which cattle are fed no grain, but instead rotated among paddocks of irrigated pasture for 12 months. A 103-hectare circle of pivot-irrigated pasture land would be created on freshly cleared cerrado land, using water from an hypothesised river or well. Lime and phosphorus would be added before planting pasture grass to support 1,100 calves. ${ }^{66}$ The system requires minimal labour-one person can manage three pivots, and the cheapest land can be used, that which cannot support rain-fed agriculture. ${ }^{67}$ The cerrado has a six-month dry season, making irrigation essential, yet little thought has been given to the actual sources of irrigation water or water for cattle concentrated in feedlots. Furthermore, there is no mention of waste-management methods. Intensified cattle production with fertilised pastures on extremely well-drained soils with a low ability to retain nutrients could pose a threat to aquifers and nearby surface water, although the soils' renowned ability to fix phosphorus might mitigate against this form of water contamination.

Ecosystem integrity and function are unvalued, as plans call for environmental transformation to suit industrial scales of production. These completely technological approaches to land use only consider the price of land, soil amendments and labour as costs of production. A central assumption is that by moving biofuels cultivation to lesser-valued (and incorrectly imagined lower carbon content) grasslands, forests will be spared. Ignorance of grasslands' significant subterranean ecology has enabled the privileging of forest land in terms of carbon storage and environmental protection. Environmental histories of large-scale interventions in grassland ecosystems in other places for other purposes have uncovered unintended consequences. Lack of information about local conditions was always central to the environmental and social disruptions caused. ${ }^{68}$

65 ibid.

66 Cerrado soils are notorious for their capacity to fix phosphorus, making them unavailable for plant growth. AgBrazil states that 'fertility on cerrado soils is "man made", requires extensive modification, and takes timeup to 3 years under some conditions'. AgBrazil, 'Soils', www.agbrazil.com/soils.html, accessed 6 November 2015 (site discontinued).

67 L. Pretto de Azevedo and J. C. C. Saad, 'Irrigação de pastagens via pivô central, na bovinocultura de corte', Irriga 14, no.4 (October-December 2009): 492-503, doi.org.10.15809/irriga.2009v14n4p492-503.

68 For example, Thomas J. Bassett and Donald Crummey, African Savannas: Global Narratives and Local Knowledge of Environmental Change (London: James Curry; Portsmouth, NH: Heinemann, 2003); Kate B. Showers, Imperial Gullies: Soil Erosion and Conservation in Lesotho (Athens, OH: Ohio University Press, 2005). 


\section{Summary and conclusions}

Denying both the finiteness of the earth's surface and the importance of functioning ecosystems to human existence has been central to the promotion of biofuels as a response to mitigating carbon emissions. This was enabled by the simplified world of globalised statistics. The GAEZ model family has been used to analyse alternative uses of land at a global scale. Different versions and parameter selection produced both maps of economically defined marginal land on the African continent and tables of newly defined global spare land.

Although conveniently homogeneous for the purposes of national and global levels of discussion, modelled landscapes do not reflect the significant particularities of local places, which is the scale on which all crop production occurs. Both the World Bank/IFPRI's African Guinea Savannah Zone and IIASA/FAO's global spare land are simply rearrangements of databases and models based on self-referencing-and insular-citations. The modelled and mapped African Guinea Savannah Zone, that is easily downloaded from authoritative institutional websites (including those of IFPRI and FAO), apparently documents the often-repeated colonial claim of large amounts of unused African land ready for agricultural exploitation.

To avoid the food-versus-fuel debate, GAEZ v.3.0 was used to promote thirdgeneration biofuels. In response to criticism that earlier versions of GAEZ had identified the Amazon and Congo River basin rainforests as potential arable land, version 3.0 selected the world's endangered grasslands as available non-agricultural land. Even the most superficial environmental histories of the selected regions demonstrate complex ecosystems and biomes whose values have not been recognised by industrial societies. Many of these regions have soils with severe constraints for agriculture, unreliable and largely inadequate rainfall, and harsh climates. Most have been used for centuries, if not millennia, by indigenous people. Where intensified land-use systems have been introduced, soils have been exhausted or destroyed. With expansion, entire biomes would be threatened.

The world's grasslands have greater significance than as potential venues for biofuels cultivation. Research is beginning to document the richness of their rhizospheres, the importance of soil-plant interactions for sustaining these biomes, and grasslands' significance for climatic feedback systems and extensive carbon storage. Because they are the least understood, they are the least valued and the least protected ecosystems in the world. Yet their loss would have grave consequences. Once destroyed, they cannot be restored, and the earth and its processes will have been changed fundamentally — at local, regional and global scales.

Third-generation biofuels are amenable to computer modelling because the industrial systems proposed to obliterate, rather than respond to, local environments. Technological interventions are designed to replace biological processes. In such 
systems, the most important soil qualities are tolerance of large and heavy implements, and drainage sufficient for irrigation. Rather than being complex bodies, soils are reduced to easily modified mediums for plant growth, and cattle to stationary, rapid protein producers. This approach, already causing problems and distortions on richly endowed American prairie soils, will certainly induce imbalances in more fragile soil-plant ecosystems. The long-term and indirect consequences could echo crises associated with other international agricultural development projects, and confirm the environmental fears of the Mozambican farmers who resisted industrial agriculture in their grassland ecosystem. Model-identified potential exists only in a terrain of pixels, and it is only on this socially constructed landscape that thirdgeneration biofuels could thrive.

It is possible to abandon the destructiveness of globalised statistics' simplified world view-and it is essential that we do so. The actions of human beings have so transformed the surface of the earth that all biogeophysical processes have been profoundly disrupted. Many local and regional feedback systems fundamental to global processes have been severely damaged, if not completely destroyed. This began on a small scale, but accelerated as advances in technology changed human capacities for intervention. Mitigation cannot be implemented at a global scale. It can only happen at a local level, where individuals, institutions and communities take actions to restore or protect their soil and water systems. It will be the cumulative effect of local actions that will begin to ameliorate local disturbed ecosystems. These will feed into larger regional and, ultimately, global systems and processes. If the global earth crises we are now facing are the cumulative effect of discrete, local destructive steps, mitigation can only be achieved by the reverse: the cumulative effect of discrete, local restorative measures over significant periods of time.

Biofuels can provide an alternative to fossil fuels, but applying an industrial approach to their production simply continues the destructive logic responsible for global degradation. When included in soil-conserving farming systems, biofuels could supply local fuel needs. Small-scale production would not only create local self-sufficiency, but also reduce local demand for fossil fuels. If linked to strongly reduced electricity consumption, then not only local, but regional and global consumption of fossil fuels would be reduced. Rivers further threatened by dams could be protected. A new ethic is required. Developing and acquiring new technologies that increase humanity's separation from itself as well as from the earth must be identified as destructive, while consuming less, wasting little and becoming reconnected with nature should be promoted as primary goals. 
This text is taken from International Review of Environmental History, Volume 6, Issue 1, 2020, edited by James Beattie, published 2020 by ANU Press, The Australian National University, Canberra, Australia.

doi.org/10.22459/IREH.06.01.2020.03 